\title{
Managing a World Heritage Site in the Face of Climate Change: A Case Study of the Wet Tropics in Northern Queensland
}

\author{
Ellen T. Weber ${ }^{1}$, Carla P. Catterall ${ }^{2}$, John Locke ${ }^{3,4,5}$, Liz S. Ota ${ }^{6}$, Bruce Prideaux ${ }^{7}$, Leslie Shirreffs ${ }^{1,8}$, \\ Leah Talbot ${ }^{9}$ and Iain J. Gordon $10,11,12,13,14,15, *$ (D)
}

1 Wet Tropics Management Authority, Cairns, QLD 4870, Australia; Ellen.Weber@wtma.qld.gov.au (E.T.W.); wettropics@wtma.qld.gov.au (L.S.)

2 School of Environment and Science, Griffith University, Nathan, QLD 4111, Australia; c.catterall@griffith.edu.au

3 Rainforest Aboriginal Peoples' Strategic Custodial Think Tank, Cairns, QLD 4870, Australia; john@biocultural.com.au

4 BioCultural Consulting P/L, Maroochydore, QLD 4558, Australia

5 University of South Australia, Adelaide, SA 5000, Australia

6 Tropical Forests and People Research Centre, University of the Sunshine Coast, Maroochydore DC, QLD 4558, Australia; lota@usc.edu.au

7 Central Queensland University, Cairns, QLD 4870, Australia; b.prideaux@cqu.edu.au

8 Climate Change Working Group, Australian World Heritage Advisory Committee, Australian Government, Canberra, ACT 2601, Australia

9 Great Barrier Reef Foundation, 300 Ann Street, Brisbane, QLD 4000, Australia; LTalbot@barrierreef.org

check for updates

Citation: Weber, E.T.; Catterall, C.P.; Locke, J.; Ota, L.S.; Prideaux, B.; Shirreffs, L.; Talbot, L.; Gordon, I.J. Managing a World Heritage Site in the Face of Climate Change: A Case Study of the Wet Tropics in Northern Queensland. Earth 2021, 2, 248-271. https://doi.org/10.3390/earth 2020015

Academic Editors: Terri Schulz and Timothy Kittel

Received: 12 April 2021

Accepted: 27 May 2021

Published: 1 June 2021

Publisher's Note: MDPI stays neutral with regard to jurisdictional claims in published maps and institutional affiliations.

Copyright: (C) 2021 by the authors Licensee MDPI, Basel, Switzerland. This article is an open access article distributed under the terms and conditions of the Creative Commons Attribution (CC BY) license (https:/ / creativecommons.org/licenses/by/ $4.0 /)$.
10 Fenner School of Environment and Society, The Australian National University, Canberra, ACT 2601, Australia

11 James Hutton Institute, Aberdeen AB15 8QH, UK; adrian.manning@anu.edu.au

12 Central Queensland University, Townsville, QLD 4810, Australia

13 Land \& Water, CSIRO, Townsville, QLD 4810, Australia

14 Protected Places Mission, NESP2, Reef and Rainforest Research Centre, Cairns, QLD 4870, Australia

15 Lincoln University, Lincoln 7647, Canterbury, New Zealand

* Correspondence: iain.gordon@anu.edu.au; Tel.: +61447411258

\begin{abstract}
World Heritage is the pinnacle of the recognition of the natural, aesthetic, and cultural value of a place on the planet. Since its inception in 1972, over 1100 sites have received World Heritage status. Many of these places are being challenged by the effects of climate change. Urgent action is needed to build the resilience and adaptive capacity of World Heritage sites in the face of climate change threats to come. The Wet Tropics of Queensland World Heritage Area (WTWHA) is one of the most effectively regulated and managed protected Areas in the world. This includes the scientific evidence upon which that regulation and management is based. However, there is growing evidence that climate change impacts are a clear and present threat to the Outstanding Universal Value (OUV) upon which the listing is based. This challenges the very concept of OUV and points to the business-as-usual regulation and management not being sufficient to deal with the threat. It also calls for quantum changes in the approaches to protecting natural and cultural heritage and the OUV in World Heritage Areas. This WTWHA case study gives insights into the journey travelled and the pathways that need to be laid out to protect our most cherished internationally recognised natural and cultural landscapes. We demonstrate the importance of evidence in support of advocacy and management action to address the clear impacts of climate change on species, ecosystems, people, and societies living in the WTWHA. The strategic and climate adaptation plans provide the framework upon which these actions take place. Community engagement in the delivery of mitigation, adaptation, and resilience policy is key to the long-term future of the WTWHA.
\end{abstract}

Keywords: World Heritage; Wet Tropics; climate change; adaptation; impacts; cultural values; Outstanding Universal Values; OUV; resilience 


\section{Introduction}

World Heritage is the pinnacle of the recognition of the natural, aesthetic, and cultural value of a place on the planet. Since its inception in 1972, 1121 sites have received World Heritage status. Many of these places are being challenged by the effects of climate change. For example, it is predicted that 42 World Heritage sites in the Mediterranean are currently at flood risk or impacted by coastal erosion associated with climate change [1]. The Great Barrier Reef, on the eastern seaboard of Australia, has recently been damaged by cyclones and coral bleaching from sea surface temperate rise, again associated with climate change [2]. Urgent action is needed to build the resilience and adaptive capacity of World Heritage sites in the face of the climate change threats to come.

Here, we use the Wet Tropics of Queensland World Heritage Area (WTWHA) as a case study to show the impacts of climate change on aspects of its OUV and broader global biodiversity and cultural significance. We then move to assess how action is being, and must be, taken to build the reliance and adaptive capacity of the WTWHA. This case study clearly demonstrates the importance that scientific evidence has played in activating climate activism and in the planning processes, community education and engagement, and management of a World Heritage site. We use this case study to discuss the broad needs of the World Heritage Area family to assess and address climate change impacts on OUV, and the potential threat of climate change to the concept of World Heritage as currently defined.

\section{A Gem of Regulation and Protection}

The WTWHA occupies Queensland's north eastern portion of the Great Dividing Range. The Area comprises $8940 \mathrm{~km}^{2}$ [3] of mainly rainforest from Townsville to just south of Cooktown and west to the Atherton Tablelands, with the highest point being Mount Bartle Frere South Peak at just over 1600 m (Figure 1). The Area encompasses the world's oldest continuously surviving tropical rainforest, with evidence of rainforest existing on these mountain ranges for over 130 million years. It is also home to the one of the world's oldest living cultures-Rainforest Aboriginal Peoples have been living in the rainforest environments for at least 5000 years. Before European settlement, the Wet Tropics rainforests were one of the most diversely populated Areas of Australia, and the only place where Australian Aboriginal people permanently inhabited a tropical rainforest environment [4].

Rainforest Aboriginal people developed a specialised and distinctive cultural heritage determined by their dreamtime and creation stories, as well as their traditional food gathering, processing, and land management techniques. Reliance on their traditions helped Rainforest Aboriginal people to live year-round in the rainforests of the WTWHA. The distinctiveness of the traditions and technical innovation and expertise needed to process and prepare toxic plants as food, and the use of fire, has been recognised under national environmental law [5].

The WTWHA rainforests received UNESCO World Heritage listing for all four natural criteria in 1988 and was recognised on the Australian National Heritage list for its cultural values in 2012. It is one of 12 natural World Heritage Areas in Australia. The four natural World Heritage criteria for which the Area is listed are:

- natural phenomena or beauty;

- major stages of Earth's history;

- significant ecological and biological processes;

- significant natural habitat for biodiversity. 


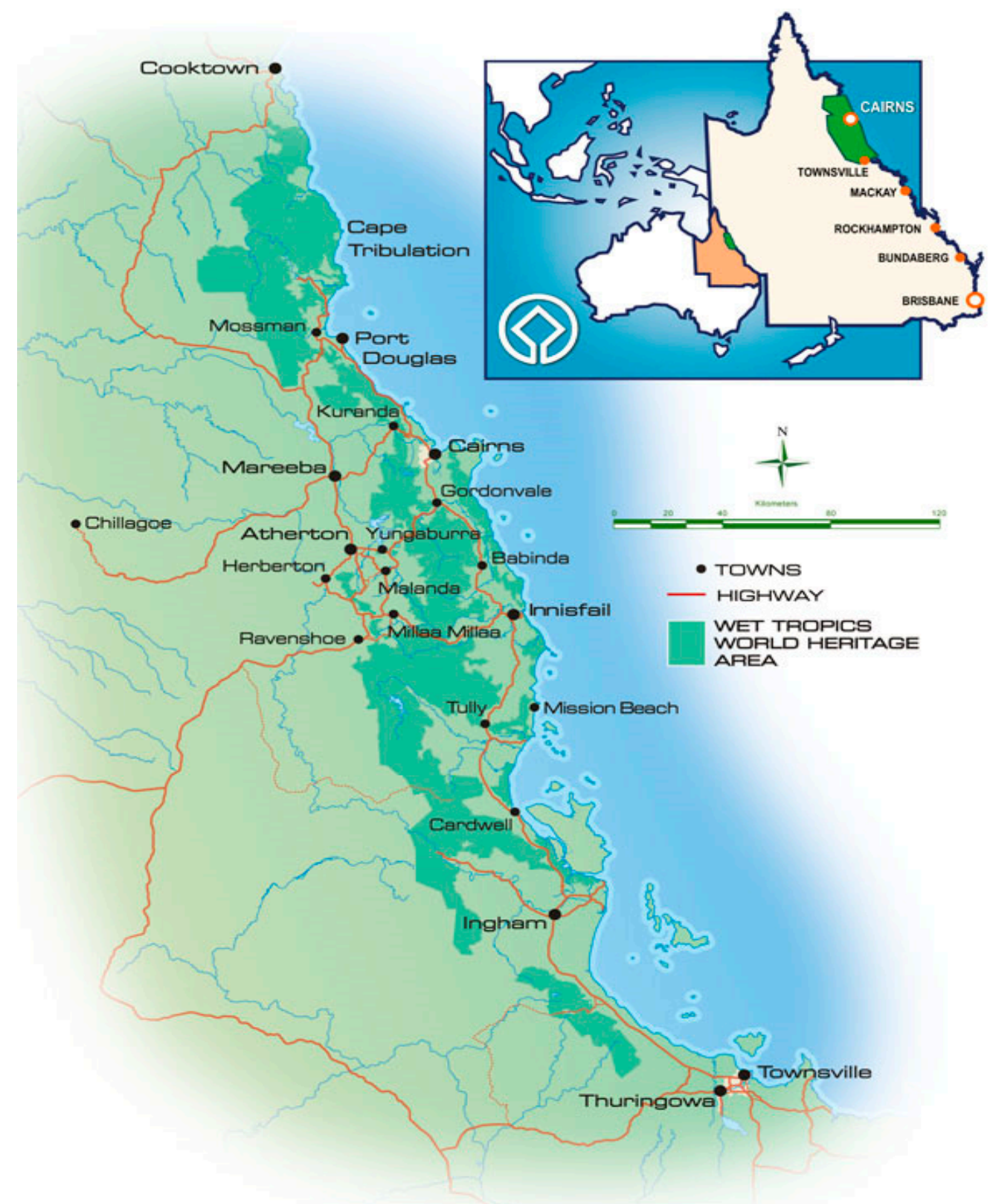

Figure 1. The Wet Tropics and the World Heritage Area lie on the north eastern seaboard of Australia, adjacent to the Great Barrier Reef.

The unique biodiversity, and its significance in understanding evolutionary history, makes the WTWHA one of the most important regions in the world. The Area retains the largest expanses of rainforest in Australia, supporting the highest level of biodiversity of any region in Australia. Covering just $0.12 \%$ of Australia, the Area is home to an exceptionally high proportion of the nation's biodiversity (Figure 2). 


\section{The rich biodiversity of the Wet Tropics World Heritage Area}

\section{3,300+ PLANT SPECIES \\ $700+$ of which are endemic}

700+ VERTEBRATE SPECIES

88 of which are endemic

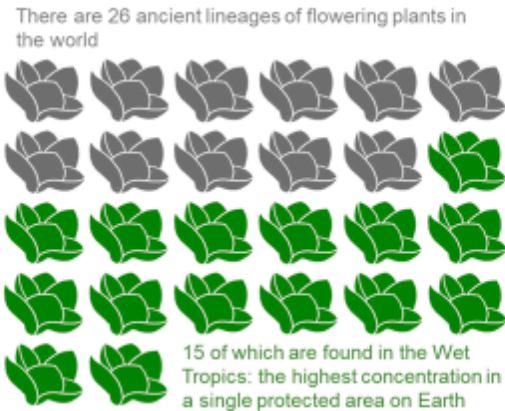

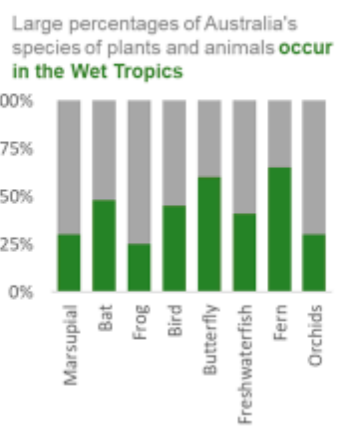

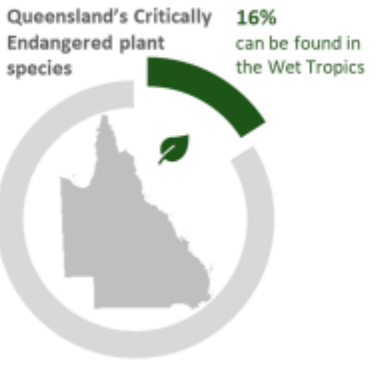

Figure 2. The rich biodiversity of the Wet Tropics World Heritage Area.

Assessed as the second most irreplaceable natural World Heritage site on Earth by the International Union for the Conservation of Nature (IUCN), the WTWHA sits in the top $0.1 \%$ of the most important protected areas in the world [6].

\section{The History and Legislation}

Following its World Heritage listing, in 1990 the Commonwealth and State governments agreed to jointly fund and coordinate management of the Wet Tropics Management Authority (the Authority) signing an Intergovernmental Agreement that established the WTWHA Management Scheme. This agreement outlined broad structural and funding arrangements, including the establishment of a statutory authority. The Authority has an independent Board comprising six part-time directors nominated by the Commonwealth and State governments, and a full time Executive Director. At least two of the nominees of the Board is to be an Aboriginal person with an interest in the land [7]. The management scheme also establishes a scientific advisory committee to provide advice to the Authority, and a community consultative committee to report to the Authority providing the viewpoint of representative interest groups and the broader community. Both of these committees are chaired by a member of the Board.

The Authority works in partnership with a range of land managers, including Queensland Parks and Wildlife Service (85\% of the World Heritage Area is in the protected Area network), Rainforest Aboriginal Peoples, a range of local governments, community service infrastructure providers, industries, organisations, and the regional community in delivery of the management of the Area.

The Wet Tropics World Heritage Protection and Management Act 1993 (Queensland Act), and the Commonwealth Wet Tropics of Queensland World Heritage Conservation Act 1994 (Commonwealth Act) give legal effect to the administrative and governance aspects of the agreement and facilitate the implementation of Australia's obligations under the World Heritage Convention. These Acts require the Authority to produce an annual State of the Wet Tropics World Heritage Area report for both the State and Commonwealth parliaments.

The Queensland Act provides the legal basis for the Wet Tropics Management Plan 1998 (the Management Plan) that regulates land use activities in the Area through a zoning and permit system including a penalty regime for infringements. Under the Management Plan, the Authority is required to consider a set of principles and criteria for deciding 
permit applications of which the most important consideration is the likely impact of a proposed activity on the integrity of the property.

While the Management Plan applies to all lands within the Wet Tropics, the property contains a diversity of different tenures, and a corresponding range of government agencies and private land holders with responsibilities for managing these tenures, under different legislation. Since listing, the Queensland Government has transferred most former forestry tenures to protected Area tenure. This has resulted in the total of protected Area estate being increased from 14\% in 1980 to around 85 percent in 2020 (Figure 3). Native Title and other Rainforest Aboriginal Peoples' land interests now cover at least $87 \%$ of the Area [8]. The conversion to protected Area estate theoretically ensures a more compatible conservation management regime.

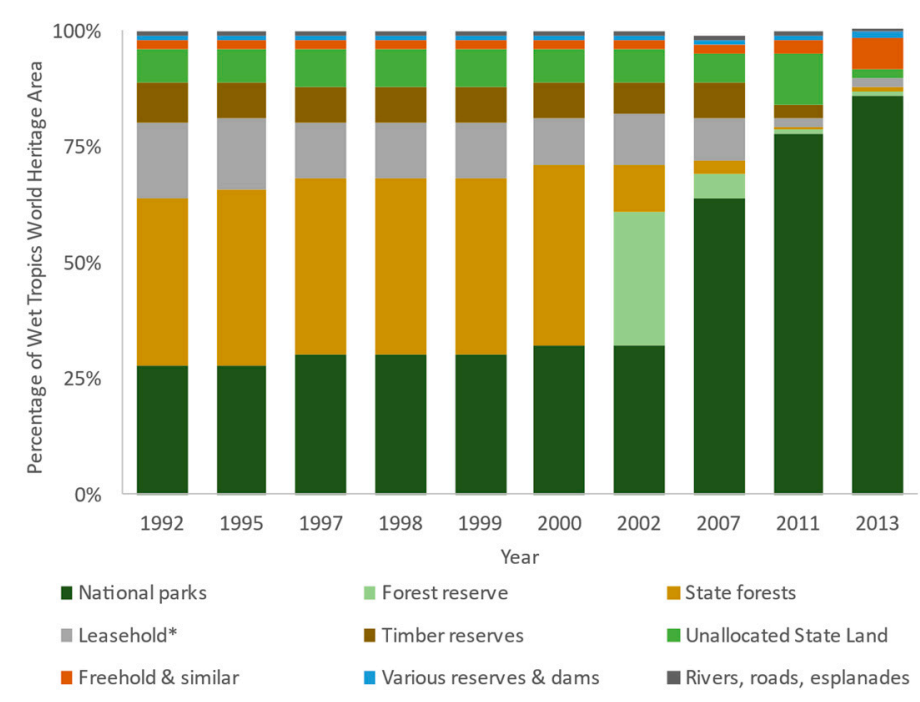

Figure 3. Proportional trends in land tenure in the Wet Tropics World Heritage Area from 1992 to 2013 (data source: Wet Tropics Management Authority).

The Commonwealth's Environment Protection and Biodiversity Conservation Act of 1999 (EPBC Act) provides an additional layer of protection for all World Heritage properties in Australia. Under the EPBC Act, any action that has, will have, or is likely to have, a significant impact on the World Heritage values of a World Heritage property must be referred to the responsible Commonwealth Environment Minister for consideration. The EPBC Act applies whether the activity is inside or outside of the boundaries of a World Heritage property. Substantial penalties apply for taking such an action without approval. In 2007, the Wet Tropics was added to the Australian National Heritage List, in recognition of its national heritage significance (https:/ / www.wettropics.gov.au/nationalheritage-listing, accessed on 1 January 2021) under the EPBC Act, including its importance in exhibiting the aesthetic characteristics valued by a community or cultural group.

As well as the regulatory protection mechanisms described above, the Authority has prepared several contemporary strategies to guide management of the property, including the Wet Tropics Sustainable Tourism Plan 2020-2030, the Strategic Plan 2020-2030, and the Climate Adaptation Plan 2020-2030. The Climate Adaptation Plan sets out a vision for Wet Tropics community to be recognised as a world leader in successful adaptive management of World Heritage in response to climate change. This will be achieved under three goals the including the establishment of inclusive regional adaptation planning frameworks; improving landscape resilience; and facilitating a transition to adaptive communities and industries.

The Authority is committed to promoting and developing partnerships with people and stakeholders with rights, responsibilities and interests associated with the Wet Tropics. Since 2005, Wet Tropics Strategic Plans have included Rainforest Aboriginal Peoples' rights, 
interests, and responsibilities embedded in World Heritage management. This recognises that Rainforest Aboriginal Peoples are the traditional custodians of the Wet Tropics region. There are at least 20 Rainforest Aboriginal tribal groups, 120 clans and 8 language groupscurrently over 20,000 people-with ongoing traditional connections to land and waters in the Area. Rainforest Aboriginal Peoples have adapted to a range of climatic, environmental, and social changes and continue to have obligations for the management of their country under traditional lore and customs. Several Rainforest Aboriginal groups have become legally recognised landowners in the Wet Tropics region. As native title interests are increasingly determined, and lands returned, pathways are being created to undertake a wider range of uses and activities. This has engaged Rainforest Aboriginal Peoples to undertake master planning processes for community development, to achieve return to country aspirations, develop economic opportunities, and enter joint management arrangements for national parks (currently being negotiated for the Daintree National Park) through tenure resolution processes. Such collaborative partnership approaches have seen Rainforest Aboriginal Peoples develop a leadership group that progresses annually mandated resolutions that address customary and cultural strategic management with strategic World Heritage management issues, impacts and actions.

\section{Evidence of Investment in Protection and Management}

The Wet Tropics Management Authority was established in 1992, delivering and reporting on the Management Plan and to the World Heritage Committee since that time. IUCN, the international advisory body for World Heritage, produces a three-yearly World Heritage Outlook report [9]. Despite a strong framework of management and protection, the last three reports have consistently cited that the Wet Tropics World Heritage Area remains of "Significant Concern". This is primarily because of the potential impacts of climate change, invasive weeds, pests, and diseases.

The same report states that the overall protection and management is "Mostly Effective" with the release of the review of the statutory Wet Tropics Management Plan 1998 in September 2020, and the fact that there are policies and procedures in place ensuring the sound management of the Area, cited as contributing to this rating.

\section{Seeing the Signals and Predicting Their Impacts of Climate Change}

The rainforests of the Wet Tropics World Heritage Area were forged in ancient and longterm cycles of change in climate dating back to the time of the supercontinent Gondwana. However, the rate at which the climate is changing due to greenhouse gas emissions is now regarded as the single biggest threat to the future of the Outstanding Universal Value (OUV), and integrity for which the Area was inscribed onto the World Heritage List in 1988.

The climate change threat to biodiversity in the Wet Tropics is well documented (Supplementary Material). The IUCN World Heritage Outlook 3 Report states that "climate change has emerged as a major threat to biodiversity and can exacerbate impacts of other threatening processes such as fragmentation, pests/weeds and changed water and fire regimes". There is already evidence of changes in the abundance and distribution of fauna.

\subsection{Weather}

Wet Tropics Regional Climate Projections

The Intergovernmental Panel on Climate Change (IPCC) [10] is 95\% confident that human activities are changing Earth's climate, even with allowances made for natural variability. Climate change projections for the Wet Tropics are well documented [11,12] while historic changes also give an eye into the future climate of the region. 
Briefly, without strong intervention to prevent global warming, the Wet Tropics will continue to be impacted the following 12 climate stressors (refer Table 1 and Figure 4):

1. Air temperature change (higher minimum and maximum temperatures and more frequent hot days)

2. Change in wind-stronger trade winds

3. Hydrology and occult precipitation (cloud stripping)

4. Drought frequency and severity

5. Humidity changes (higher evaporation)

6. Rainfall changes and variability (more extreme rainfall events, uncertainty around the models)

7. Tropical cyclone intensity and frequency (fewer but more intense)

8. Water temperature increase and increased acidity

9. Storm surge

10. Sea level change

11. Abiotic factors-e.g., fire weather (frequency, intensity, intervals)

12. Increased carbon dioxide concentrations

Table 1. An assessment of the World Heritage attribute that contributes to the Outstanding Universal Value of the Wet Tropics, and if climate change will impact on that criteria (data source: Wet Tropics Management Authority Scientific Advisory Committee).

\begin{tabular}{|c|c|c|c|c|c|c|c|c|c|c|c|c|c|}
\hline \multirow{2}{*}{$\begin{array}{c}\text { World Heritage Attribute that } \\
\text { Contributes to the OUV of the Wet } \\
\text { Tropics }\end{array}$} & \multirow[t]{2}{*}{ WH Criteria } & \multicolumn{12}{|c|}{ Climate Stressor Identified for the Wet Tropics } \\
\hline & & 1 & 2 & 3 & 4 & 5 & 6 & 7 & 8 & 9 & 10 & 11 & 12 \\
\hline $\begin{array}{l}\text { Scenic vistas where rugged forested } \\
\text { landscapes meet intact coastal ecosystems }\end{array}$ & vii, viii & & & & & & & $\checkmark$ & & & $\checkmark$ & $\checkmark$ & \\
\hline $\begin{array}{l}\text { Rugged mountains peaks, escarpments and } \\
\text { gorges }\end{array}$ & vii, viii & & & & & & & $\checkmark$ & & & $\checkmark$ & $\checkmark$ & \\
\hline Rivers, natural waterbodies and waterfalls & vii & & & $\checkmark$ & $\checkmark$ & $\checkmark$ & $\checkmark$ & $\checkmark$ & & & & & \\
\hline $\begin{array}{l}\text { Emotional, intellectual, material and/or } \\
\text { spiritual sense of, and attachment to place }\end{array}$ & vii, viii, ix, $x$ & $\checkmark$ & $\checkmark$ & $\checkmark$ & $\checkmark$ & $\checkmark$ & $\checkmark$ & $\checkmark$ & & & & $\checkmark$ & \\
\hline $\begin{array}{l}\text { Intact record of the evolution of the major } \\
\text { stages of plant life on earth }\end{array}$ & viii & & $\checkmark$ & $\checkmark$ & $\checkmark$ & $\checkmark$ & $\checkmark$ & $\checkmark$ & & & & $\checkmark$ & \\
\hline Taxa that represent ancient lineages & viii, ix, $x$ & $\checkmark$ & & $\checkmark$ & $\checkmark$ & $\checkmark$ & $\checkmark$ & $\checkmark$ & $\checkmark$ & & & $\checkmark$ & $\checkmark$ \\
\hline Endemic taxa & viii, ix, $x$ & $\checkmark$ & & $\checkmark$ & $\checkmark$ & $\checkmark$ & $\checkmark$ & $\checkmark$ & $\checkmark$ & & & $\checkmark$ & $\checkmark$ \\
\hline High biodiversity & viii, ix, $x$ & $\checkmark$ & $\checkmark$ & $\checkmark$ & $\checkmark$ & $\checkmark$ & $\checkmark$ & $\checkmark$ & $\checkmark$ & $\checkmark$ & $\checkmark$ & $\checkmark$ & $\checkmark$ \\
\hline Threatened, endemic ecosystems & ix, $x$ & $\checkmark$ & $\checkmark$ & $\checkmark$ & $\checkmark$ & $\checkmark$ & $\checkmark$ & $\checkmark$ & $\checkmark$ & $\checkmark$ & $\checkmark$ & $\checkmark$ & $\checkmark$ \\
\hline $\begin{array}{l}\text { Intact ecotones between rainforest and } \\
\text { sclerophyll communities }\end{array}$ & ix $x$ & $\checkmark$ & & & $\checkmark$ & $\checkmark$ & $\checkmark$ & $\checkmark$ & & & & $\checkmark$ & $\checkmark$ \\
\hline $\begin{array}{l}\text { Ongoing ecological processes and } \\
\text { biological evolution }\end{array}$ & $i x, x$ & $\checkmark$ & $\checkmark$ & $\checkmark$ & $\checkmark$ & $\checkmark$ & $\checkmark$ & $\checkmark$ & $\checkmark$ & $\checkmark$ & $\checkmark$ & $\checkmark$ & $\checkmark$ \\
\hline Climate refugia (past, present and future) & ix,$x$ & $\checkmark$ & $\checkmark$ & $\checkmark$ & $\checkmark$ & $\checkmark$ & $\checkmark$ & $\checkmark$ & $\checkmark$ & $\checkmark$ & $\checkmark$ & $\checkmark$ & $\checkmark$ \\
\hline
\end{tabular}




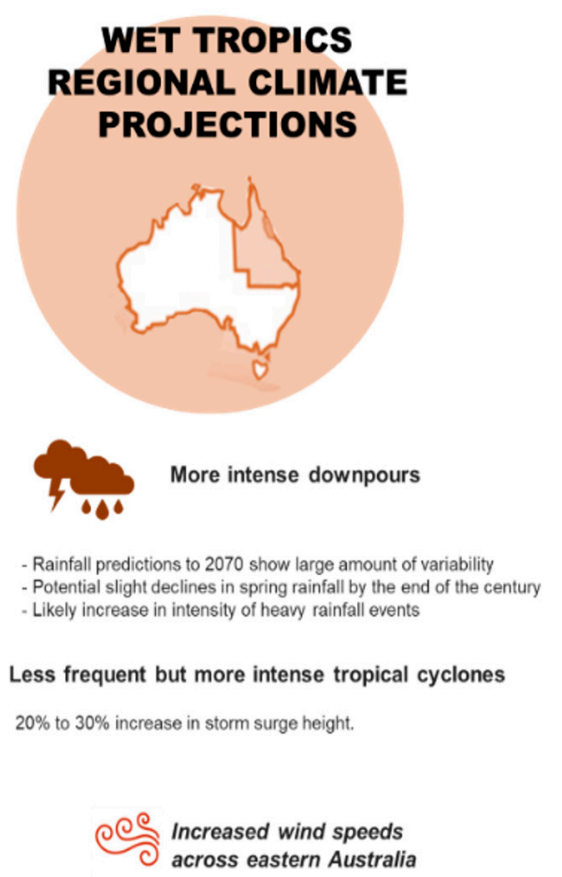

\section{HIGHER TEMPERATURES}

More extreme temperature spells: likely substantial increase in the

temperature reached on the hottest days and in the frequency of hot days

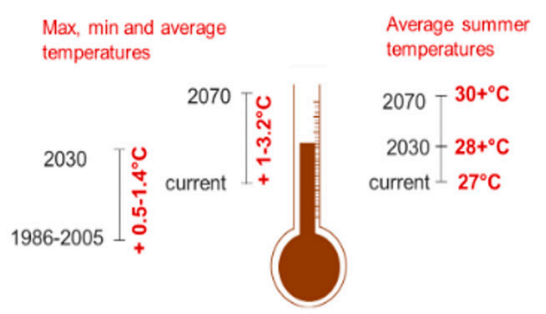

Uncertain changes to fire frequency
Fire weather conditions expected to worsen
Fires likely to be more extreme

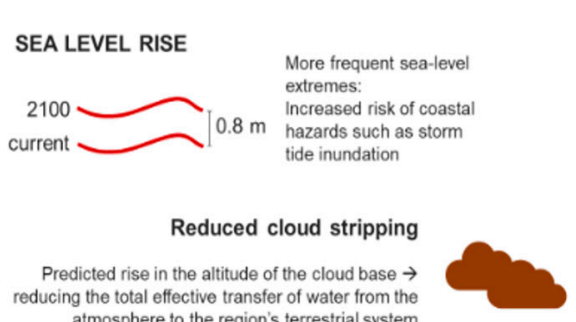

Figure 4. Wet Tropics regional climate projections. Data source [13].

\subsection{Flora and Fauna}

While some of the regional climate projections are dealing with scenarios up to 50 years into the future, there is significant evidence that climate change is already affecting the Wet Tropics World Heritage Area. For example, long-term monitoring in the Wet Tropics has already highlighted declines in the distribution and populations of many rainforest species due to climate change [14], and in 2019, record temperatures at the Area's mountain peaks were recorded years before they were expected to occur (Queensland Parks and Wildlife Service, unpublished data). Large-scale changes in the distribution of species and complete turnover of future ecosystems are predicted as responses to climate change. Climate change is, therefore, likely to impact ecosystem processes such as recruitment, dispersal, pollination, and migration.

\subsubsection{Abundance and Distribution of Key Species}

Climate change is leading to changes in the distribution of suitable climate space for many species, and these species must either acclimatise or move if they are to persist [15]. Already, there is evidence of species movement, particularly in mountaintops where cooladapted species are moving to higher altitudes. Habitat connectivity will be important for species needing to move, meaning some species will be impacted by changing climate when this connectivity does not exist because of forest fragmentation [16].

Many Wet Tropics endemic species are only found in the cooler, higher altitude parts of the region $[17,18]$. It is these species that played a key role in the World Heritage listing for the Wet Tropics, but they are the most vulnerable to climate change impacts. By 2070, under a high greenhouse gas emissions scenario, the climates that currently characterise some upland environments may disappear entirely, leading to substantial loss of biodiversity [17].

\subsubsection{Upland Flora}

The recent modelling of habitat suitability for 19 Wet Tropics endemic plants, entirely restricted to mountaintops, have made predictions of a decline in suitable habitat for each of the 19 species by a minimum of $63 \%$ and up to $100 \%$ by 2040 [19]. The potential resilience of the ancient lineage species to climate change cannot be determined due to a lack of 
detailed knowledge of their distributions, life history characteristics, physiology, ecological tolerances, and relative competitive abilities. Lowland species could migrate with the projected shift in tropical and subtropical environments, but their capacity to respond in this way will be severely constrained by habitat fragmentation.

\subsubsection{Upland Vertebrate Fauna}

The iconic, endemic rainforest ringtail possums of the Wet Tropics World Heritage Area are in trouble. Primarily restricted to higher elevations across the Wet Tropics, their plight under climate change was raised more than 17 years ago, with models suggesting that they could face extinction by the end of this century. Since then, long-term monitoring, combined with improved distribution modelling and physiological research, has supported these concerns: declines in ringtail populations in the region are consistent with the impacts of a warming climate.

Possum populations have declined in the lower, warmer parts of their range and initially increased in the upper elevations. The most sensitive species appears to be the Lemuroid Ringtail possum (Hemibelideus lemuroides). In the northern population (Mt Lewis) the number of individuals crashed after a heat wave in 2005 and no individuals were seen for several years followed by a slow recovery. In the southern population centred on the Atherton Tableland, Lemuroid possums started disappearing at lower elevations, and while until about 2010 abundance increased at $800 \mathrm{~m}$ and $1000 \mathrm{~m}$ sites, it has been in decline ever since. The core population at the $800 \mathrm{~m}$ long-term monitoring site has now declined to approximately $25-30 \%$ of pre-2008 numbers.

Additional monitoring sites in this area have recently been established in collaboration with QPWS rangers, however, the possum numbers at these new sites match the trends in the longer-term sites. At the current rate of decline, the Lemuroid population, at $800 \mathrm{~m}$ elevation, will disappear within the next two to five years. These observed declines are graver than even the most severe future predictions under the IPCC RCP8.5 scenario that predict a 50\% decline by 2035-2045 [20].

Herbert River Ringtails (Pseudochirulus herbertensis) have disappeared from $600 \mathrm{~m}$ elevation since 2008 , declined by more than $50 \%$ at $700 \mathrm{~m}$ and have been relatively stable, or even increasing slightly, thus far at $800 \mathrm{~m}$ and higher, although there are signs of a declining trend in recent data.

Green Ringtail Possums (Pseudochirops archeri) increased in abundance at higher elevations above $800 \mathrm{~m}$ from 1992-2008, although numbers have declined somewhat over the last two years. The data available on Daintree River Ringtails (Pseudochirulus cinereus) is insufficient for robust statistical analysis at this stage.

Wet Tropics rainforest birds, particularly endemic species, are suffering serious declines; two decades of research is demonstrating declines in abundance and shifts in species' distribution consistent with a warming climate [21]. Bird species that are rainforest specialists have declined by an average of $20 \%$ and endemic species by $34 \%$. In contrast, the local abundance of habitat generalists, mostly widespread species, have increased. These trends are associated with upward shifts to the cooler, higher elevation of lowland species, and a decline of $44 \%$ in upland rainforest specialists and regional endemics. The spatial pattern of the declines provides additional support for the hypothesis that increasing temperature, particularly heat waves, is the primary driver [22]. These documented population declines are supported by several other bird monitoring projects in the region and have recently resulted in 14 regionally endemic bird taxa being nominated for threatened status (three Endangered, seven Vulnerable and three Near Threatened) in the 2021 Action Plan for Australian Birds (also refer to Appendix A) [23].

Bioclimatic models suggest that climate change will have catastrophic effects on many of the region's endemic vertebrate species. Based on current distributional range limits, an increase in regional average temperature of $1.0{ }^{\circ} \mathrm{C}$ could decrease the distributional range of the region's endemic vertebrate species by $60 \%$ [24]. A not inconceivable climate change prediction of $+3.5^{\circ} \mathrm{C}$ could reduce the distribution of endemic vertebrates to around $5 \%$ 
of their current range. The projected warming of this magnitude also predicted a loss of approximately $65 \%$ of Wet Tropics endemic vertebrates. This implies a strong likelihood of approximately 50 species becoming globally extinct from the Wet Tropics World Heritage Area with only a moderate average temperature increase. Most upland endemic vertebrate species will disappear under the worst-case scenarios with temperature increases of $5.0^{\circ} \mathrm{C}$ or more $[25,26]$.

With each modelled increase in temperature, it is evident that patches of climatically suitable habitat become smaller, fragmented, and more isolated (Figure 5). Any of the described temperature increase scenarios would be catastrophic to the values for which the Wet Tropics World Heritage Area was listed. Increasing the area's knowledge of the declines of threaten vertebrate species and exploring mechanisms to inform potential management options is critical to protecting these iconic species that are so important to the Outstanding Universal Value of the World Heritage Area.

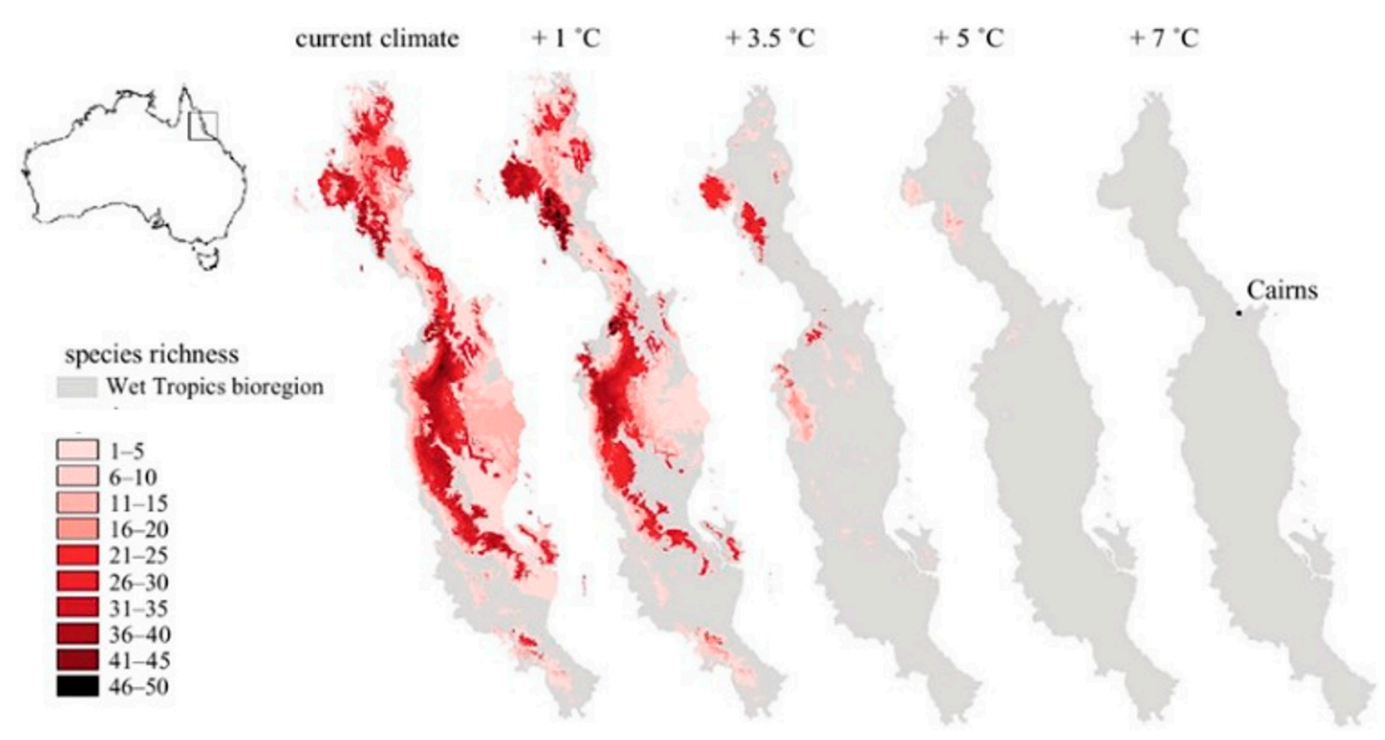

Figure 5. Geographical pattern of species richness of regionally endemic rainforest vertebrates at each temperature scenario. Species richness is produced by overlaying all species-distribution models at each temperature scenario [25].

\subsubsection{Invasive Species}

Although many species are likely to be negatively affected by climate change, the greatest community and ecosystem impacts may come from native or exotic plant or animal species that are favoured by changed conditions, such as competitors, predators, and invasive native species $[27,28]$. Climate change will likely increase the number and intensity of disturbance events-fires, drought, or cyclones-in the Wet Tropic [29,30], placing greater stresses on native species and ecosystems. Weeds, which often outcompete native species, are already one of the most serious threats to Australian biodiversity [31]. There is a huge pool of invasive plants available to colonise bare spaces. Vines and woody invasive species that are shade-tolerant and recruit from the seedling layer may constitute the greatest threat to the Wet Tropics following severe storms.

Some weeds - like Miconia calvescens (Miconia), the 'purple plague' — establish after disturbances, like cyclones, but persist as the canopy closes again, growing and producing seeds. After the next major cyclone disturbance, they are ready to germinate in far greater numbers, dominating areas and excluding all native species, as they have done in areas of Hawai'I [32]. Other weed species, such as Chromolaena odorata (Siam weed) are extremely fast growing with the capacity to scramble over existing vegetation, displacing native vegetation, and increasing the fire hazard [33]. Currently, most of these potential 'ecosystem engineers' are managed, but resources are required to maintain vigilance and take swift action to eradicate or contain emerging threats. 
Invasive ant species, such as the yellow crazy ant (Anoplolepis gracilipes) and electric ants (Wasmannia auropunctata) are already present in the Wet Tropics region [34]. There are significant investments from the State and Commonwealth Governments to control and eradicate these species. However, there is clear evidence of their impacts in other areas if the species get out of control and climate change is likely to affect the detection and the efficiency of eradication programmes for these invaders [35].

A shift of suitable habitat for existing species creates the opportunity for new and, as of yet unidentified, invasive threats. For example, species already present in Australia in low abundance may thrive in the Wet Tropics under more favourable conditions brought on by climate change.

\subsection{Abiotic}

\subsubsection{Fire}

2019 was Australia's hottest and driest year on record [36]. Evidence suggests that climate change is causing, and will continue to cause, increases in the severity and duration of fire weather. This is likely to lead to significant changes in fire regimes in the Wet Tropics, but there are not yet any specific projections about fire risk in or around the Wet Tropics rainforests due to the complexity of climate-fire-vegetation interactions. Such forecasts are urgently needed so that we can plan and secure the capability to manage this threat to natural ecosystems and communities.

More extreme fire weather, and changes in the timing and or quantity of rainfall, will affect fuel load and combustibility, and will likely alter fire regimes. The rainforest, previously considered a natural fire barrier, is now vulnerable to fire [37]. The Wet Tropics region can expect more frequent and more intense fires due to hotter temperatures, more droughts, longer periods of low humidity, carbon dioxide-induced increases in vegetation biomass and smaller windows of opportunity for prescribed burns. Invasive weeds are likely to interact with climate change to also alter fire regimes in the Wet Tropics.

Aboriginal cultural burning was a common activity once carried out by the Rainforest Aboriginal Peoples, but since European settlement that has mostly disappeared. Recently, there has been a drive to revive Aboriginal cultural burning practices across the Wet Tropics through partnerships between Rainforest Aboriginal People and QPWS. This emergent land management approach could provide many lessons and clues for more effective future management involving fire regimes in the Area.

\subsubsection{Waterways and Rivers}

Climate change is expected to not only result in severe adverse impacts on habitats and wildlife within the Wet Tropics World Heritage Area, but also affect the ecosystem goods and services the area provides, many of which support economic activities [38] (refer Table 2). For example, the supply of a secure and safe water supply supports the quality of life of residents, ensures good public health, and fosters the economic growth and development of the region [39].

\subsubsection{Cloud Stripping and Consequences for Water Supply}

High-elevation rainforests, which are immersed in clouds for a large proportion of the year, strip considerable amounts of moisture from passing clouds-a process known as occult precipitation, or cloud stripping. Wet Tropics high-elevation rainforests behave like giant sponges, capturing large volumes of water directly from clouds, which they then release slowly throughout the year. Studies have revealed $[40,41]$ that cloud forests contribute much more moisture to waterways than lower-elevation forests because trees at higher elevation grow more slowly and, therefore, use less of the harvested water. This process is important in maintaining stream flows throughout the dry season and is considered significant to the overall water budget of the region, especially in terms of water recharge during the dry season. 
Table 2. Examples of ecosystem goods and services provided by the Wet Tropics World Heritage Area and are under threat from climate change.

\begin{tabular}{|c|c|c|c|}
\hline $\begin{array}{l}\text { Maintenance of the } \\
\text { Environment }\end{array}$ & Utilitarian Uses & Personal Benefits & Ethics \\
\hline $\begin{array}{ll}\text { - } & \text { carbon cycles } \\
\text { - } & \text { water cycles } \\
\text { - } & \text { regional climates and } \\
\text { - } & \text { } \text { flood mitigatimate } \\
\text { - } & \text { groundwater recharge } \\
\text { - } & \text { pollination } \\
\text { - } & \text { pest control } \\
\text { - } & \text { habitat } \\
\text { - } & \text { refugia } \\
\text { - } & \text { water regulation } \\
\text { - } & \text { waste breakdown } \\
\text { - } & \text { country and homelands }\end{array}$ & $\begin{array}{ll}\text { - } & \text { water supply } \\
\text { - } & \text { water quality } \\
\text { - } & \text { tourism } \\
\text { - } & \text { recreation } \\
\text { - } & \text { genetic resources } \\
\text { - } & \text { scientific discovery } \\
\text { - } & \text { education } \\
\text { - } & \text { horticulture } \\
\text { - } & \text { food } \\
\text { - } & \text { pharmaceutical } \\
& \text { products }\end{array}$ & $\begin{array}{ll}\text { - } & \text { enjoyment } \\
\text { - } & \text { aesthetic pleasure } \\
\text { - } & \text { inspiration } \\
\text { - } & \text { serenity } \\
\text { - } & \text { leisure activities } \\
& \text { (photography, } \\
& \text { bushwalking, mountain } \\
& \text { biking, birdwatching, } \\
& \text { camping) } \\
\text { - } \quad \text { lifestyle } \\
\text { - } \quad \text { sense of place } \\
\text { - } \quad \text { national identity } \\
\text { - } \quad \text { mental well-being }\end{array}$ & $\begin{array}{ll}\text { - } & \text { ethical/moral values } \\
\text { - } & \text { intrinsic natural values } \\
\text { - } & \text { and importance } \\
\text { - } & \text { historic values } \\
\text { - } & \text { existence values } \\
\text { - } & \text { spiritual values }\end{array}$ \\
\hline
\end{tabular}

Under current climate conditions, cloud stripping occurs in rainforests more than $600 \mathrm{~m}$ above sea level. With every degree of warming the base of the cloud condensation layer is predicted to rise by an average of $100 \mathrm{~m}$ [42]. Rainfall changes are unclear. We may expect a temperature rise of up to $3.0^{\circ} \mathrm{C}$, equating to a rise in the effective cloud stripping condensation layer from $600 \mathrm{~m}$ to $900 \mathrm{~m}$ above sea level. In this scenario, the effective cloud stripping Area in the Wet Tropics will decrease by as much as 40\% [43], meaning significantly reduced water yields for Wet Tropics waterways, especially in the dry season.

\subsection{Wider Climate Impacts: Cultural and Economic}

The Wet Tropics alone provides over $\$ 5$ billion annually of ecosystem services to the communities of the region [44], including clean water, aesthetic, and cultural values. This includes the $\$ 2.6$ billion associated with the tourism industry, plus at least an additional $\$ 2.6$ billion generated by non-market values associated with the worth the community places on the natural assets [45].

\subsubsection{Cultural}

Rainforest Aboriginal Peoples are important inhabitants and land managers across the Wet Tropics who are likely to be directly and indirectly affected by climate change in many ways. Elders of Rainforest Aboriginal Peoples are already raising the issue of totem animals' ranges moving out of the clan areas and the impacts of increased and severity of fires will themselves limit opportunities for going on country and managing country in traditional ways. Rainforest Aboriginal Peoples are highly sensitive to climate changeinduced ecosystem change because of the close associations between healthy country, physical and mental well-being, and cultural practices. Rainforest Aboriginal Peoples' traditional knowledge about land and sea will be a valuable contributor to adapting to, and dealing with, climate change in the Wet Tropics [46-48].

\subsubsection{Tourism, Agriculture, and Horticulture}

Along with high biodiversity, there are numerous and substantial economic and cultural values associated with the rainforests of the Wet Tropics, including agriculture and tourism. Outside of the protected Area estate there are multiple, and sometimes conflicting, demands for use of natural resources. Climate change is likely to exacerbate these issues and challenges.

Agriculture (mainly sugar cane and horticulture) generates $\$ 1.62$ billion annually from the region [49]. Both sugar cane and horticulture are heavily dependent on natural resources and the ecosystem services these natural resources provide. Agriculture in the 
Wet Tropics region is likely to be challenged by climate change, requiring adaptations in where, what, and how food is produced in the region. There are also likely to be extreme event impacts, as has been seen for the banana industry post Cyclone Larry [50]. The sector's responses will flow on to other sectors.

Tourism associated with the natural assets of the Great Barrier Reef and the Wet Tropics World Heritage Area brings in over \$11 billion per annum to the region. We have already seen the response of the tourism sector to perceived declines in the health of the Reef; climate change impacts could, therefore, have ongoing and long-term consequences for the region's economy and communities.

There are over 230 managed and unmanaged visitor sites within the Wet Tropics World Heritage Area [51] and tourism generates on average $\$ 2.6$ billion annually across the Wet Tropics region [52-54]. From the sites that have a high-volume of tourists because they are easily accessible through to more remote locations including waterfalls, lookouts, and waterholes, each forms an important part of the Wet Tropics' overall visitor site portfolio. Many of these sites are threatened in some way by climate change including:

1. reduced access due to flooding and high sea levels;

2. deteriorating aesthetic value;

3. reduced visitor comfort with rising temperatures and unpredictable weather patterns; 4. increased perceived risk of visiting destination due to extreme weather events [55].

Recognising the short- and long-term impacts on tourism and agriculture is a start, but support will need to be provided to build the resilience of individuals and industries in the face of climate change in the region. It should also be noted that tourism can have negative impacts on biodiversity already affected by climate change and so tourism will have to be carefully managed [56].

\section{Responding to the Signals}

\subsection{Developing the Advocacy}

The greenhouse gas emissions that are responsible for human induced climate change is a global issue and citizens and national governments must support immediate action for the reduction of carbon din the atmosphere in alignment with the Paris Agreement. In addition, World Heritage sites are also perfect places to mitigate climate action at the local, regional, and national level. World Heritage site managers should work to limit emissions across their own sites (management, tourism, other economic activities, etc.), and advocate from local to (inter)national levels to mitigate climate change.

In early 2019 a special out of session Board meeting of directors of the Wet Tropics Management Authority called to the national leadership for urgent action and investment following new evidence of escalating climate change impacts on the Wet Tropics of Queensland World Heritage Area. The Board released a statement and 10-point plan [57]. The statement highlighted the serious threat of climate change to the Wet Tropics World Heritage Area and noted that most recent science data indicated 'Extreme heat poses a real and significant threat to the Area's mountain adapted species, like the lemuroid ringtail possum, which are unable to survive even a day of temperatures above $29^{\circ} \mathrm{C}$ and called for urgent action and government investment to improve the resilience and protection of the Wet Tropics of Queensland World Heritage Area. The Board stated that it was optimistic that the collaboration and investment on a range of activities and actions now will ensure the Wet Tropics World Heritage Area, the world's oldest living rainforest, is as robust as possible to withstand increasing temperatures.

At the same time, a forum of Rainforest Aboriginal Peoples from across the Wet Tropics sent a strong resolution to a First Nations Climate Summit, held in Brisbane on 4 June 2019 [58]. An excerpt from that statement reads "our lands, seas and waters are under imminent threat from climate change, with escalating decline of the Area's plant and animal species already being observed due to increasing temperatures, changed fire patterns and extreme weather events. The Wet Tropics Management Authority must consider the threats posed by a changing climate to the Area's natural and cultural values 
and to the spiritual, material, intellectual and emotional features of the landscapes and seascapes. The Authority's ambition is that tribal knowledge systems and western science is brought together to identify ways forward to address those threats and impacts, and influence action to improve the resilience of the Area's lands, seas, and waters. Climate change will, and already is, further disconnecting the Area's people from the lands, seas, and waters and from the Area's ancestral spirits connected to Country. We call on the Australian, Queensland and local governments to take strong action on climate change."

\subsection{Developing the Climate Adaptation Plan}

With all the indicators pointing to the extreme pressures facing the WTWHA because of climate change the Authority had to act. The Authority felt it was necessary to develop a separate climate adaptation and resilience plan, that also aligned with the Strategic Plan 2020-2030. Whilst there was a lot of work already underway to address some of these threats, the magnitude of the challenge meant that "out-of-the-box" and intervention solutions needed to be considered, to help nature 'take its course'.

The Wet Tropics Management Authority's Accept, Act, Adapt: Climate Adaptation Plan for the Wet Tropics 2020-2030 [59] was developed in consultation with the Wet Tropics community, and outlines a strategic framework to guide its vision of " ... successful adaptive management of World Heritage in response to climate change." by

1. Establishing inclusive regional adaptation planning frameworks.

2. Improving landscape resilience.

3. Facilitating transition to adaptive communities and industries.

In line with this framework, the following practical steps aim to reduce the impacts of climate change on the region's biodiversity, primarily through adaptive responses. This will be achieved through in-situ conservation of species and ecological communities, facilitating their natural adaptation by rehabilitation, and restoring the Wet Tropics World Heritage Area's overall ecological resilience, and engaging with local, national, and international communities to garner support for actions in support of species and ecological communities.

\subsection{Establish Inclusive Regional Adaptation Planning Frameworks}

The Authority needs to increase the efficiency of planning processes for climate adaptation in the Wet Tropics region, and establish mechanisms that enable cross-sectoral planning. Responding to climate change is unlikely to succeed if it is done in isolation from other land management activities and other agencies involved in land management. Improved regional-scale coordination of adaptation planning will help align adaptation priorities, avoid duplication of effort, promote opportunities to learn from experiences, and avert consultation fatigue among shared stakeholders. For a landscape response to be meaningful, all those affected need to be brought together to deliver integrated approaches to natural resource and land management problems (including the neighbours and adjoining land managers across the Wet Tropics region). This includes government agencies, industries, Rainforest Aboriginal Peoples, scientific institutions, tourists, and regional communities (Table 3). For instance, we propose the action items listed in Table 3.

\subsection{Improve Landscape Resilience}

Many management responses to climate change, such as pest and weed management and creating wildlife corridors, are already being undertaken to improve Wet Tropics integrity. For example, we already know what species of tree to plant in degraded landscapes and the responses of biodiversity to this restoration [60,61]. However, there are still information gaps, such as the long-term impacts of plantings on faunal species and ecosystems services. Such on-ground practical land and conservation activities will become more urgent, and priorities may alter in the light of climate change to ensure additional environmental and socioeconomic co-benefits. The Authority, and its partners' response, needs, 
therefore, to be placed within an adaptive management framework: plan, act, monitor, review (Table 3).

Table 3. How policy and management support can the Wet Tropics World Heritage Area to cope with climate change.

\begin{tabular}{|c|c|c|}
\hline $\begin{array}{c}\text { Establish Inclusive Regional } \\
\text { Adaptation Planning Frameworks }\end{array}$ & Improve Landscape Resilience & $\begin{array}{l}\text { ptive } \\
\text { ies }\end{array}$ \\
\hline $\begin{array}{l}\text { Improve the coordination and } \\
\text { integration of information across a } \\
\text { range of adaptation plans and } \\
\text { projects across the Wet Tropics. This } \\
\text { will ensure that adaptation is better } \\
\text { mainstreamed into all relevant } \\
\text { organisations work. } \\
\text { Develop and support } \\
\text { decision-making mechanisms that } \\
\text { provide realistic opportunities for } \\
\text { engagement with existing and new } \\
\text { stakeholders. } \\
\text { Support processes that demonstrate } \\
\text { innovative adaptive planning and } \\
\text { share these learnings. Collaborate } \\
\text { with partners to secure the practical } \\
\text { support required to deliver these } \\
\text { programs. } \\
\text { Incorporate equitable and culturally } \\
\text { appropriate processes for including } \\
\text { Traditional Ecological Knowledge } \\
\text { and tribal science in adaptation } \\
\text { decision-making for managing the } \\
\text { Wet Tropics. } \\
\text { Increase knowledge about change in } \\
\text { Wet Tropics biodiversity and } \\
\text { ecosystems to develop appropriate } \\
\text { management responses and to } \\
\text { reduce the risk of continuing } \\
\text { ineffective or maladaptive planning. } \\
\text { Work to ensure that natural } \\
\text { systems-including associated } \\
\text { ecosystem services and Rainforest } \\
\text { Aboriginal Peoples' cultural } \\
\text { values-are cross-cutting themes in } \\
\text { other sectors' plans to address } \\
\text { climate-induced vulnerability. } \\
\text { and innovation research framework } \\
\text { and implement, to support long } \\
\text {-term adaptive management. }\end{array}$ & $\begin{array}{l}\text { Identify high-risk species and } \\
\text { ecosystems to better understand } \\
\text { trends and inform management } \\
\text { responses and investment decisions. } \\
\text { Secure protection for high priority } \\
\text { at-risk habitat in locations that are } \\
\text { expected to provide climatic refugia } \\
\text { for biodiversity. } \\
\text { Implement strategic management of } \\
\text { invasive species and diseases, } \\
\text { updated to incorporate knowledge } \\
\text { about impacts of climate change on } \\
\text { future distributions and emerging } \\
\text { issues, together with understanding } \\
\text { about key ecological processes. } \\
\text { Identify high priority refugia and } \\
\text { conduct on-ground works that } \\
\text { increase the diversity, condition and } \\
\text { availability of micro-climate refugia, } \\
\text { including habitat elements and } \\
\text { topographic features that provide } \\
\text { shelter during climatic extremes. } \\
\text { All Wet Tropics land managers to } \\
\text { implement appropriate fire regimes } \\
\text { in response to a variable and } \\
\text { changing climate to fire sensitive } \\
\text { ecosystems such as rainforests. } \\
\text { Support research and monitoring } \\
\text { led by Rainforest Aboriginal } \\
\text { Peoples, including approaches } \\
\text { based on Traditional Ecological } \\
\text { Knowledge and experience of } \\
\text { adaptation to historic climate risks. }\end{array}$ & $\begin{array}{l}\text { Pursue options to increase } \\
\text { collaborative research into the } \\
\text { current and (uncertain) future states } \\
\text { of Wet Tropics natural systems, } \\
\text { including manipulative } \\
\text { experimentation (The Daintree } \\
\text { drought experiment https:/ / www. } \\
\text { tern.org.au/The-Daintree-drought- } \\
\text { experiment-bgp2911.html). Identify } \\
\text { potential socio-ecological links, e.g., } \\
\text { indirect impacts of climate change } \\
\text { on communities and regional } \\
\text { economies through change in } \\
\text { ecosystem services. } \\
\text { Explore potential for science-based } \\
\text { interventions such as gene banking, } \\
\text { assisted gene flow, captive } \\
\text { populations, assisted migration, } \\
\text { translocation and genetic editing. } \\
\text { Seek and promote opportunities for } \\
\text { cultural, social and economic } \\
\text { co-benefits of building adaptive } \\
\text { capacity in natural systems, } \\
\text { including green infrastructure, } \\
\text { ecosystem-based emergency } \\
\text { management, biodiversity offsets } \\
\text { and carbon sequestration programs. } \\
\text { Empower the community through } \\
\text { supporting community led } \\
\text { initiatives that increases } \\
\text { participation in adaptation action } \\
\text { across the Wet Tropics. } \\
\text { Implement trials of direct } \\
\text { interventions, restoration and } \\
\text { management works that facilitate } \\
\text { ecosystems transition, for example } \\
\text { by allowing novel changes in } \\
\text { composition but maintaining } \\
\text { ecosystem functions. }\end{array}$ \\
\hline
\end{tabular}

\subsubsection{Broadening the Engagement with the Community}

Whilst the are several no-regrets actions (those that are likely to have few downsides, e.g., native tree planting, corridor establishment), that have been identified, and priorities that have been set, this is by no means a comprehensive list (Table 3). All actions must be embedded within an adaptive management framework that allows the "best of our knowledge" on-ground work to be applied, monitored, and reviewed so that continuous improvement can occur. The planning stage, at the beginning of each lap of the adaptive management cycle, will have to be informed by the state of play of relevant knowledge, including engagement with Rainforest Aboriginal Peoples. 
Education, including through the school curricula, is an important component of developing a broader understanding of the issues and impacts associated with climate change to the Wet Tropics. Education and awareness raising will also enthuse the community to support and take action in support of mitigation and adaptation approaches to helping the Authority in delivery of its Climate Adaptation Plan. As well as a number of community events (including the annual Cassowary Awards), there is a Youth Education Implementation Plan in place that is being delivered in partnership with the education and youth sector, with a specific focus on the impacts of climate action.

\subsubsection{Facilitate Transition to Adaptive Communities and Industries}

Social and economic trends that affect the region's vulnerability to climate change and the social, cultural, and financial impacts under new and/or unstable climatic conditions across the Wet Tropics landscapes are not well understood (Table 3).

\subsection{Innovating to Tackle Climate Change in the Wet Tropics}

Wet Tropics researchers have developed a decision framework aimed at guiding managers and policy makers in a way that considers the various adaptation options, ranging from the least expensive and most likely to have benefits to the more costly and risky actions [62].

It is important to stress that many of the common environmental management practices such as control of invasive species, appropriate fire regimes, minimizing fragmentation are all important for maintaining future resilience of the Wet Tropics rainforest.

\subsubsection{Rainforest Refugia}

The identification and preservation of refugia Areas will be essential in the long-term conservation of species in the region. Climatically buffered microhabitats within pristine rainforests will likely serve as another line of defence against extreme weather events. These small microhabitats remain cool and wet during hot conditions and should provide conditions that species can survive in, at least over short timeframes-for example, a heat wave [63].

Large-scale refugial Areas will, however, ultimately be required for successful longterm conservation of populations. These Areas can be identified using spatially explicit modelling approaches that capitalise on long-term data of species distributions and climate modelling in the region [64].

\subsubsection{Innovative Approaches}

Intervention may also be needed to support at-risk species using innovative approaches such as creation of artificial habitat, biomimicry, genetic engineering, and establishment of ex-situ populations $[65,66]$.

A last resort is the consideration of assisted colonisation and ex-situ conservation; however, these approaches are likely to be expensive, present ethical dilemmas, and not guaranteed to succeed, particularly for fauna. Research is, therefore, required now on the methodology and efficacy of these more radical actions, in the event in-situ conservation options prove ineffective $[67,68]$.

The high elevation forests of the Wet Tropics World Heritage Area harbour more than 100 species of plants that are found nowhere else on Earth. Recent modelling studies [69] on a subset of those species showed that for 25 of 37 species analysed, climate-driven habitat loss will exceed $90 \%$ by 2085 , and seven species will lose their habitat entirely. As a response, researchers from the Australian Tropical Herbarium and James Cook University have partnered with several botanic gardens and relevant Rainforest Aboriginal Peoples' groups to undertake an ex-situ conservation program to 'back up' at-risk wild populations and support research, display, and education. The team is pursuing novel research on seed banking strategies, genetic diversity, and plant tolerance of extreme climates to ensure that the reserve germplasm collections, comprising live plants and stored seed distributed 
across multiple botanic gardens and seed banks along Australia's east coast, incorporate high redundancy (to guard against accidental loss), are genetically and physiologically diverse (to maximise resilience) and climatically matched to wild habitat. Captive breeding populations could be established for plant and animal species at high risk of extinction. However, a triage review would need to be done to establish species that have a high priority, are suitable for captivity and have future options for release back to the wild.

\subsubsection{Increased Monitoring}

To fully understand the consequences of long-term climate change, and to respond accordingly to population decline, more long-term monitoring of populations will be required. Long-term data are paramount for informing and triggering successful management actions in the region under an adaptive management approach [70].

\subsubsection{Community Collaboration}

Climate change-induced ecosystem impacts in the Wet Tropics will inevitably affect human communities and the industries that depend on them. The magnitude of these impacts will largely depend on the willingness and capacity of the local community to collaborate in developing and undertaking management responses. Effective management, therefore, requires the employment of strategies that are socially and economically sustainable, and co-designed with local communities. Research is required to support management approaches based on evidence of community engagement and social license to operate.

\section{Relevance for Other World Heritage Sites}

The Wet Tropics is not alone in experiencing the impacts of climate change or staring down the barrel of future catastrophic human induced species extinctions. For example, the neighbouring Great Barrier Reef World Heritage site has suffered a series of environmental catastrophes, including sea surface temperature rise leading to coral bleaching in three out of the past five years [71]. The World Heritage Committee is currently redrafting a set of guidelines for World Heritage sites on climate vulnerability and adaptation (the policy was last reviewed in 2009). Abundantly evident across the World Heritage Areas globally, is that upgrading a parcel of land to a more secure public protected tenure declaring for conservation does not necessarily buffer it from the impacts of climate change. A key issue is what do climate change impacts mean for the recognition of World Heritage sites? The baseline OUV upon which sites were listed (e.g., the Great Barrier Reef in 1980) have altered since its listing; does this mean that the listing of that site must be reviewed? Do we accept a shifting baseline for World Heritage listing which means that we now have a lower bar for OUV than we did 30 years ago? These are all fundamental questions about the meaning of recognition of places as natural (and cultural) wonders of the world.

Back in the 1970s and 1980s, when many iconic WHAs were inscribed, there was an implicit assumption that achieving spatial and physical protection of the land parcels (and in some cases the patterns of their traditional human use and occupancy) would be sufficient to protect OUV. Since the 1990s, emerging knowledge about both climate change and the off-site impacts of expanding human land use, technology, and population, demonstrates that this assumption is no longer valid [72]. This is a key challenge for WHAs globally. Revising the OUV may be part of the toolbox for addressing this (with many potential risks associate with assessing management effectiveness of a World Heritage site with a variable baseline). Since many challenges arise from off-site threats and processes, it is becoming more important to engage with off-site entities and collaborators.

It is also clear that despite having an effective governance and management system in place the biodiversity of the Wet Tropics is still under significant threat from climate change, weeds, pests, and diseases. These threats are not independent of each other and require significant investment of resources if they are to be addressed successfully. For example, the ongoing project to eradicate the yellow crazy ant from the Wet Tropics has costed 
\$6 million per annum since 2016. Many World Heritage sites do not have the governance, management, or funding bases upon which to address the challenges they face from a range of threats. Resource constraints, a need for more specialist skills and guidance, and differing levels of interest and motivation in the issue were amongst the major challenges for developing and implementing climate-change adaptation policies [73]. But this requires capacity and resources that many WHAs do not have, despite obligations under the Convention concerning the Protection of the World Cultural and Natural Heritage (the World Heritage Convention) obliging signatories to "undertake appropriate legal, scientific, technical, administrative and financial measures necessary for the identification, protection, conservation, presentation and rehabilitation of heritage" [74].

The Wet Tropics is fortunate to have an independent board of directors and established advisory committees in place with a strong research community working in the region. This information forms the baseline upon which trends in species, ecosystems, and ecological processes can be assessed. The long-term monitoring is a key part of the needs for understanding the threats, however, it is clear from the situation in the Wet Tropics that there must be fundamental shifts in management and innovative mechanisms to address the threat, particularly of climate change. These move away from the idea that has been the foundation of conservation for decades, that protection is the key to sustaining biodiversity in place. New ex-situ conservation methods are urgently needed that protect biodiversity e.g., gametes, seeds, eggs, individuals, species) and in-situ active environmental intensification that protects biodiversity in place [75]. These include active approaches to restoring and adding resilience and adaptive capacity to communities and ecosystems. And out-of-the-box approaches to protecting valuable biodiversity hot spots, including novel engineering solutions (see e.g., the Reef Restoration and Adaptation Program, a partnership to help the Great Barrier Reef, resist, adapt and recover) [76].

Even within the Wet Tropics World Heritage Area, the implementation of monitoring and management actions has relied on resources and funds that are decided and delivered through independent agencies or other bodies. In the case of the Wet Tropics, many of these are state based, although natural resource management (NRM) bodies and nongovernment organisations are gaining in profile. This dependence on externally based monitoring and management is an ongoing and increasing challenge because the priorities of those agencies are set by issues other than the specific OUV listings associated with the WHA (even though there is some overlap in goals). Again, the Authority addresses this challenge by using mechanisms to engage and collaborate. But there have been forward and backward steps in this process.

The Wet Tropics does not sit in isolation; it is neighbour to over 2500 properties to the north, south and west of the Area. Also, on the east is the Great Barrier Reef Marine Park, of course, itself a World Heritage Area. At present there is little interaction between the Authorities responsible for the management of the two World Heritage Areas. This must change as there are lessons to be learnt across the Areas and opportunities for collaboration in the management approach to the climate change challenges.

\section{Conclusions}

Climate impacts are already evident in the Wet Tropics World Heritage Area. Without significant change in the emissions of greenhouse gases the following climate change impacts are likely in the Wet Tropics:

1. Many species, especially cool-adapted mountaintop endemics, will be displaced.

2. Some ecosystems of the Wet Tropics will disappear entirely.

3. Rainforest Aboriginal Peoples will lose the bio-cultural and natural character of their landscapes and related cultural heritage sites.

4. The local community may suffer from a decline in revenue adversely affecting the local economy, jobs, and social wellbeing. Over 50 upland species could become globally extinct from the Wet Tropics World Heritage Area with only a moderate average temperature increase. 
5. Invasive species will increasingly impact native species with no natural defences.

6. Bushfire risk will increase, forcing changes to fire management regimes.

While climate change is a global issue and reducing greenhouse gas emissions is a State and national jurisdiction, the Wet Tropics Management Authority is committed to tackling the challenge at a regional, Wet Tropics-focused level, drawing on the myriad research and modelling that has already been undertaken across the area. By examining regional climate projections, their impacts on the Wet Tropics to date, and likely future impacts, it is possible to consider both long-term and more immediate, practical management responses.

The Wet Tropics is rightly held in value within the World Heritage family, however, the threats to its future from climate change are unprecedented. There is still a lot to learn and appropriate action, based on the best of our current knowledge, is urgently needed if the future for the Wet Tropics World Heritage Area is to be secured.

Author Contributions: E.T.W. and I.J.G. though of an wrote the first draft of the manuscript. All other authors provided edits and comments on the manuscript. All authors have read and agreed to the published version of the manuscript.

Funding: This research was funded by The Wet Tropics Management Authority which receives funds from both the Queensland and Australian Federal Governments.

Data Availability Statement: Not applicable.

Acknowledgments: We thank three reviewers for their constructive comments on an earlier version of this manuscript.

Conflicts of Interest: Ellen Weber is an employee of the Queensland Government (Wet Tropics Management Authority., Leslie Shirreffs and Iain Gordon are independent directors on the Board of the Wet Tropics Management Authority. All other authors are members of the Authority's Scientific Advisory Committee.

\section{Appendix A}

Wet Tropics endemic vertebrate fauna and flora predicted to be most at risk from climate change.

Note that more species are showing declines but there is insufficient data for nomination at present; Plants listed in the table below are those that will lose more than $90 \%$ of their core climate habitat by $2085[42,43]$.

\begin{tabular}{ll}
\hline Frogs & \\
\hline Cophixalus concinnus & Thornton Peak nurseryfrog \\
\hline Pseudophryne covacevichae & Magnificent broodfrog \\
\hline Cophixalus hosmeri & Rattling nurseryfrog \\
\hline Mixophyes carbinensis & Carbine barred frog \\
\hline Cophixalus neglectus & Bellenden Ker nurseryfrog \\
\hline Cophixalus exiguous & Daintree nursery frog \\
\hline Cophixalus monticola & Mountain nursery frog \\
\hline Taudactylus rheophilus & Northern tinker frog \\
\hline Mammals & \\
\hline Antechinus godmani & Atherton antechinus \\
\hline Hemibelideus lemuroides & Lemuroid ringtail possum \\
\hline Petaurus gracilis & Mahogany glider \\
\hline Pseudochirulus cinereus & Daintree River ringtail possum \\
\hline
\end{tabular}




\begin{tabular}{|c|c|}
\hline Pseudochirulus herbertensis & Herbert River ringtail possum \\
\hline Dasyurus maculatus gracilis & $\begin{array}{l}\text { Spotted-tailed quoll (northern } \\
\text { sub-species) }\end{array}$ \\
\hline \multicolumn{2}{|l|}{ Birds } \\
\hline Acanthiza katherina & Mountain thornbill \\
\hline Alisterus scapularis minor & Wet Tropics Australian King-Parrot \\
\hline Colluricincla boweri & Bower's Shrike-thrush \\
\hline Cormobates leucophaea minor & Little Treecreeper \\
\hline Gerygone mouki mouki & Wet Tropics Brown Gerygone \\
\hline Heteromyias cinereifrons & Grey-headed Robin \\
\hline Lophorina victoriae & Victoria's Riflebird \\
\hline Oreoscopus gutturalis & Fernwren \\
\hline Prionodura newtoniana & Golden bowerbird \\
\hline Psophodes olivaceus lateralis & Wet Tropics Eastern Whipbird \\
\hline Scenopoeetes dentirostris & Tooth-billed Bowerbird \\
\hline Sericornis keri & Atherton scrubwren \\
\hline Sericornis magnirostra viridior & Wet Tropics Large-billed Scrubwren \\
\hline \multicolumn{2}{|l|}{ Skinks } \\
\hline Calyptotis thorntonensis & Thornton Peak skink \\
\hline Techmarscincus jigurru & Bartle Frere cool- skink \\
\hline Saproscincus czechurai & wedge-snouted shade skink \\
\hline Saproscincus lewisi & Cooktown shade skink \\
\hline Lampropholis robertsi & Grey-bellied sun skink \\
\hline Eulamprus frerei & Bartle Frere bar-sided skink \\
\hline Glaphyromorphus mjobergi & Atherton Tableland mulch-skink \\
\hline \multicolumn{2}{|l|}{ Flowering plants } \\
\hline \multicolumn{2}{|l|}{ Acrotriche baileyana } \\
\hline \multicolumn{2}{|l|}{ Austromuellera valida } \\
\hline Bulbophyllum lilianae & Warty strand orchid \\
\hline Cinnamomum propinquum & Pepperwood \\
\hline \multicolumn{2}{|l|}{ Dracophyllum sayeri } \\
\hline Elaeocarpus hylobroma & Quandong \\
\hline Elaeocarpus linsmithii & Quandong \\
\hline Flindersia oppositifolia & Mountain silkwood \\
\hline Garcinia brassii & Mountain mangosteen \\
\hline \multicolumn{2}{|l|}{ Gynochthodes constipate } \\
\hline \multicolumn{2}{|l|}{ Gynochthodes podistra } \\
\hline Leptospermum wooroonooran & Wurunuru ti-tree, mountain teatree \\
\hline \multicolumn{2}{|c|}{ Leucopogon malayanus subsp. novoguineensis } \\
\hline Litsea granitica & Bollywood \\
\hline
\end{tabular}




\begin{tabular}{ll}
\hline Octarrhena pusilla & Wispy grub orchid \\
\hline Parsonsia bartlensis & \\
\hline Pleioluma singuliflora & Lewis coondoo \\
\hline Polyscias bellendenkerensis & \\
\hline Symplocos wooroonooran & Small-leaved hazelwood \\
\hline Syzygium fratris & \\
\hline Tasmannia sp. (Mt Bellenden Ker J.R.Clarkson 6571) & \\
\hline Trachymene geraniifolia & Geranium-leaved Trachymene \\
\hline Zieria madida & \\
\hline Conifers & Black kauri or purple kauri \\
\hline Agathis atropurpurea & \\
\hline Ferns & filmy fern \\
\hline Hymenophyllum whitei &
\end{tabular}

\section{References}

1. Reimann, L.; Vafeidis, A.T.; Brown, S.; Hinkel, J.; Tol, R.S.J. Mediterranean UNESCO World Heritage at risk from coastal flooding and erosion due to sea-level rise. Nat. Commun. 2018, 9, 4161. [CrossRef] [PubMed]

2. Hughes, T.P.; Kerry, J.T.; Álvarez-Noriega, M.; Álvarez-Romero, J.G.; Anderson, K.D.; Baird, A.H.; Babcock, R.C.; Beger, M.; Bellwood, D.R.; Berkelmans, R.; et al. Global warming and recurrent mass bleaching of corals. Nature 2017, 543, 373-377. [CrossRef]

3. United Nations Educational, Scientific and Cultural Organization (UNESCO). World Heritage List-Wet Tropics of Queensland. 1988. Available online: https:/ / whc.unesco.org/en/list/486/ (accessed on 23 February 2021).

4. Hill, R.; Baird, A. Kuku-Yalanji rainforest aboriginal people and carbohydrate resource management in the wet tropics of Queensland, Australia. Hum. Ecol. 2003, 31, 27-52. [CrossRef]

5. Australian Government Department of Agriculture, Water and the Environment. Place Details, Wet Tropics of Queensland. Available online: http:/ / www.environment.gov.au/cgi-bin/ahdb/search.pl?mode=place_detail;place_id=105689 (accessed on 1 January 2021).

6. Osipova, E.; Emslie-Smith, M.; Osti, M.; Murai, M.; Åberg, U.; Shadie, P. IUCN World Heritage Outlook 3: A Conservation Assessment of All Natural World Heritage Sites, November 2020. Gland, Switzerland: IUCN. x + 90 pp. Available online: https:/ / doi.org/10.2305/IUCN.CH.2020.16.en (accessed on 1 January 2021).

7. Queensland Government. Wet Tropics World Heritage Protection and Management Act 1993 QLD. Available online: https: / / www.legislation.qld.gov.au/view/html/inforce/current/act-1993-050 (accessed on 1 January 2021).

8. Wet Tropics Management Authority. Wet Tropics of Queensland World Heritage Area Regional Agreement. Cairns. 2005. Available online: https:/ /www.wettropics.gov.au/site/user-assets/regional_agreement.pdf (accessed on 1 January 2021).

9. International Union for the Conservation of Nature (IUCN). IUCN World Heritage Outlook. 2020. Available online: https: / / portals.iucn.org/library/node/49134 (accessed on 1 January 2021).

10. Shukla, P.R.; Skea, J.; Calvo Buendia, E.; Masson-Delmotte, V.; Pörtner, H.-O.; Roberts, D.C.; Zhai, P.; Slade, R.; Connors, S.; van Diemen, R.; et al. (Eds.) Technical Summary. In Climate change and Land: An IPCC Special Report on Climate Change, Desertification, Land Degradation, Sustainable Land Management, Food Security, and Greenhouse Gas Fluxes in Terrestrial Ecosystems; The Intergovernmental Panel on Climate Change (IPCC): Genève, Switzerland, 2019; in press.

11. Suppiah, R.; Macadam, I.; Whetton, P.H. Climate Change Projections for the Tropical Rainforest Region of North Queensland; Unpublished Report to the Marine and Tropical Sciences Research Facility; Reef and Rainforest Research Centre Limited: Cairns, Australia, 2007; 38p.

12. Chand, S.S. Climate change scenarios and projections for the Pacific. In Climate Change and Impacts; Springer: Cham, Switzerland, 2020; pp. 171-199.

13. Queensland Government. Climate change in the Far North Queensland Region. Department of Environment and Science. 2019. Available online: www.qld.gov.au/_data/assets/pdf_file/0025/68371/far-north-qld-climate-change-impact-summary.pdf (accessed on 25 February 2021).

14. Williams, S.E.; Hilbert, D.W. Climate change as a threat to the biodiversity of tropical rainforests in Australia. In Emerging Threats to Tropical Forests; Laurance, W.F., Peres, C.A., Eds.; University of Chicago Press: Chicago, IL, USA, 2006; pp. 33-52.

15. Wet Tropics Management Authority. 2015-2016 State of the Wet Tropics Report: Ancient, Endemic, Rare and Threatened Vertebrates of the Wet Tropics; Wet Tropics Management Authority: Cairns, Australia, 2016.

16. Invasive Species Council. Invasive Species and Climate Change. 2009. Available online: www.invasives.org.au/wp-content/ uploads/2014/02/fs_animalsandclimatechange.pdf (accessed on 1 January 2021). 
17. Warren, R.; VanDerWal, J.; Price, J.; Welbergen, J.A.; Atkinson, I.; Ramirez-Villegas, J.; Osborn, T.J.; Jarvis, A.; Shoo, L.P.; Williams, S.E.; et al. Quantifying the benefit of early climate change mitigation in avoiding biodiversity loss. Nat. Clim. Chang. 2013, 3, 678-682. [CrossRef]

18. Meade, J.; VanDerWal, J.; Storlie, C.; Williams, S.; Gourret, A.; Krockenberger, A.; Welbergen, J. Substantial reduction in thermo-suitable microhabitat for a rainforest marsupial under climate change. Biol. Lett. 2018, 14, 12. [CrossRef]

19. Roeble, E. Modelling the Vulnerability of Endemic Montane Flora to Climate Change in the Australian Wet Tropics. Master's Thesis, Imperial College London, London, UK, 2018.

20. Shoo, L.P.; Storlie, C.; Williams, Y.M.; Williams, S.E. Potential for mountaintop boulder fields to buffer species against extreme heat stress under climate change. Int. J. Biometeorol. 2010, 54, 475-478. [CrossRef]

21. Williams and Lam. (Unpublished data).

22. Williams, S.E.; de la Fuente, A. Long-term changes in populations of rainforest birds in the Australian Wet Tropics bioregion: A climate/biodiversity emergency. Proc. Roy. Soc. Lond. B 2021. Available online: https://usern.tums.ac.ir/User/CV/Stephen_ Williams (accessed on 1 January 2021).

23. Garnett, S.T.; Baker, G.B. Action Plan for Australian Birds 2020; CSIRO: Melbourne, Australia, 2020; in press.

24. Garnett, S.T.; Franklin, D.C.; Ehmke, G.; VanDerWal, J.J.; Hodgson, L.; Pavey, C.; Reside, A.E.; Welbergen, J.A.; Butchart, S.H.M.; Perkins, G.C.; et al. Climate Change Adaptation Strategies for Australian Birds; National Climate Change Adaptation Research Facility: Gold Coast, Australia, 2013; 925p.

25. Williams, S.E.; Bolitho, E.E.; Fox, S. Climate change in Australian tropical rainforests: An impending environmental catastrophe. Proc. R. Soc. B Boil. Sci. 2003, 270, 1887-1892. [CrossRef] [PubMed]

26. Williams, S.E.; Falconi, L. Climate Change Could Empty Wildlife from Australia's Rainforests. In The Conversation. 2015. Available online: https:/ / theconversation.com/climate-change-could-empty-wildlife-from-australias-rainforests-41023 (accessed on 1 January 2021).

27. Kaiser, B.A. Economic impacts of non-indigenous species: Miconia and the Hawaiian economy. Euphytica 2006, 148, 135-150. [CrossRef]

28. Brooks, S.; Logan, P. Management of Chromolaena odorata in the Douglas Shire. In Proceedings of the 21st Australasian Weeds Conference, "Weed Biosecurity-Protecting our Future", Sydney, Australia, 9-13 September 2018; pp. 345-349.

29. Moran, C.; Boulter, S. Biodiversity and Ecosystems Climate Adaptation Plan. Brisbane, Australia. 2018; 89p. Available online: https:/ / www.qld.gov.au/_data/assets/pdf_file/0022/87610/b-e-cap.pdf (accessed on 1 January 2021).

30. Dowdy, A.J. Climatological Variability of fire weather in Australia. J. Appl. Meteorol. Climatol. 2018, 57, 221-234. [CrossRef]

31. Dunlop, M.; Hilbert, D.W.; Stafford-Smith, M.; Davies, R.; James, C.D.; Ferrier, S.; House, A.; Liedloff, A.; Prober, S.M.; Smyth, A.; et al. Implications for Policymakers: Climate Change, Biodiversity Conservation and the National Reserve System; CSIRO Climate Adaptation Flagship: Canberra, Australia, 2012.

32. Medeiros, A.C.; Loope, L.L.; Conant, P.; McElvaney, S. Status, ecology, and management of the invasive plant, Miconia calvescens DC (Melastomataceae) in the Hawaiian Islands. Brit. Mus. Occas. Pap. 1997, 48, 23-36.

33. Hilbert, D.W.; Hill, R.; Moran, C.; Turton, S.M.; Bohnet, I.; Marshall, N.A.; Pert, P.L.; Stoeckl, N.; Murphy, H.T.; Reside, A.E.; et al. Climate Change Issues and Impacts in the Wet Tropics NRM Cluster Region; James Cook University: Cairns, Australia, 2014.

34. Loope, L.L.; Krushelnycky, P.D. Current and potential ant impacts in the Pacific region. Proc. Hawaii Entomol. Soc. 2007, 39, 69-73.

35. Lach, L. James Cook University TESS Seminar Held 11 March 2020. Available online: https://mediasite.jcu.edu.au/Mediasite/ Play / eb263da1e3594ab098b72696ec146d551d (accessed on 1 January 2021).

36. Doyle, K. 2019 Was Australia's Hottest Year on Record. Australian Broadcasting Commission. Published 2 January 2020. Available online: www.abc.net.au/news/2020-01-02/2019-was-australias-hottest-and-driest-year-on-record/11837312 (accessed on 1 January 2021).

37. Wet Tropics Management Authority. State of Wet Tropics 2019-2020: Creating Our Climate Future; Wet Tropics Management Authority: Cairns, Australia, 2020.

38. Wet Tropics Management Authority. State of Wet Tropics Report 2014/15: Economic Value of the Wet Tropics World Heritage Area; Wet Tropics Management Authority: Cairns, Australia, 2015.

39. Esparon, M.; Farr, M.; Larson, S.; Stoeckl, N. Social values and growth and their implications for ecosystem services in the long-run. Australas. J. Reg. Stud. 2018, 24, 327-346.

40. McJannet, D.; Reddell, P. Where earth meets sky: Cloud forests of the Wet Tropics. In Using Rainforest Research; Cooperative Research Centre for Tropical Rainforest Ecology and Management: Cairns, Australia, 2002.

41. Narsey, S.; Laidlaw, M.; Colman, R.; Pearce, K.; Hopkins, M.; Dowdy, A. Impact of Climate Change on Cloud Forests in the Gondwana Rainforests of Australia World Heritage Area; Earth Systems and Climate Change Hub Report No. 20; NESP Earth Systems and Climate Change Hub: Australia, 2020. Available online: https://nespclimate.com.au/wp-content/uploads/2020/09/GondwanaLCL-CS-TR-final.pdf (accessed on 1 January 2021).

42. Georgious, A. Climate Change is Stripping the Magnificent Cloud Forests of Their Clouds; Newsweek, Tech \& Science. 2019. Available online: https: / www.newsweek.com/climate-change-cloud-forests-1399098 (accessed on 1 January 2021).

43. McJannet, D.; Wallace, J.; Reddell, P. Precipitation interception in Australian tropical rainforests: II. Altitudinal gradients of cloud interception, stemflow, throughfall and interception. Hydrol. Process. 2007, 211, 703-718. [CrossRef] 
44. Cheney, A. Ecosystem Services in the Wet Tropics: A Literature Review and Economic Valuation. Independent Study Project (ISP) Collection \# 1947. 2014. Available online: https:/ / digitalcollections.sit.edu/isp_collection/1947 (accessed on 1 January 2021).

45. Gillespie Economics. Economic Activity of Australia's World Heritage Areas; Report to the Department of the Environment, Water, Heritage and the Arts; 2008. Available online: https:/ /www.wettropics.gov.au/site/user-assets/docs/gilespie-economicactivity-report.pdf (accessed on 1 January 2021).

46. Low-Choy, D.; Clarke, P.; Jones, D.; Serrao-Neumann, S.; Hales, R.; Koschade, O. Understanding Coastal Urban and Peri-Urban Indigenous People's Vulnerability and Adaptive Capacity to Climate Change; National Climate Change Adaptation Research Facility: Gold Coast, Australia, 2013.

47. Veland, S.; Howitt, R.; Dominey-Howes, D.; Thomalla, F.; Houston, D. Procedural vulnerability: Understanding environmental change in a remote indigenous community. Glob. Environ. Chang. 2013, 23, 314-326. [CrossRef]

48. Nursey-Bray, M.; Palmer, R.; Smith, T.F.; Rist, P. Old ways for new days: Australian Indigenous peoples and climate change. Int. J. Justice Sustain. 2019, 24, 473-486. [CrossRef]

49. Stokes, C.J.; Howden, S.M. Adapting Agriculture to Climate Change: Preparing Australian Agriculture, Forestry and Fisheries for the Future; CSIRO Publishing: Canberra, Australia, 2010.

50. Gooch, M.; Vella, K.; Marshall, N.A.; Tobin, R.C.; Pears, R. A rapid assessment of the effects of extreme weather on two Great Barrier Reef Industries. Aust. Plan. 2012, 50, 198-215. [CrossRef]

51. Wet Tropics Management Authority. Wet Tropics Nature Based Tourism Strategy: A Strategy for the Development and Management of Nature-Based Tourism; Wet Tropics Management Authority: Cairns, Australia, 2000.

52. Esparon, M.; Stoeckl, N.; Larson, S.; Farr, M.; Schmider, J.; Bellafquih, R.; Levers, S. How 'valuable'are the ecosystem services of the Wet Tropics World Heritage Area to residents and tourists. In Report to the National Environmental Research Program; Reef and Rainforest Research Centre Limited: Cairns, Australia, 2014.

53. Driml, S. Travel Cost Analysis of Recreation Value in the Wet Tropics World Heritage Area. Econ. Anal. Policy 2002, 32, 11-26. [CrossRef]

54. Prideaux, B.; Falco-Mammone, F. Economic Values of Tourism in the Wet Tropics World Heritage Area. Cooperative Research Centre for Tropical Rainforest Ecology and Management; James Cook University: Cairns, Australia, 2007.

55. Tourism Tropical North Queensland. Tropical North Queensland Destination Tourism Plan 2021; TTNQ: Cairns, Australia, 2020.

56. Hoogendoorn, G.; Fitchett, J.M. Tourism and climate change: A review of threats and adaptation strategies for Africa. Curr. Issues Tour. 2016, 21, 742-759. [CrossRef]

57. Wet Tropics Management Authority. A Statement from the Board of the Wet Tropics Management Authority Regarding Serious Climate Change Impacts on the Wet Tropics of Queensland World Heritage Area. 2019. Available online: https://www. wettropics.gov.au/site/user-assets / docs/2019.04.29\%20WTMA\%20board\%20climate\%20change\%20statement.pdf (accessed on 1 January 2021).

58. Queensland Government. First Nations Climate Summit Statements. 2019. Available online: qld.gov.au/statements/87511 (accessed on 1 January 2021).

59. Wet Tropics Management Authority. Climate Adaptation Plan for the Wet Tropics 2020-2030. Accept, Act Adapt; Wet Tropics Management Authority: Cairns, Australia, 2019.

60. Paul, K.I.; Cunningham, S.C.; England, J.R.; Roxburgh, S.H.; Preece, N.D.; Lewis, T.; Brooksbank, K.; Crawford, D.F.; Polglase, P.J. Managing reforestation to sequester carbon, increase biodiversity potential and minimize loss of agricultural land. Land Use Policy 2016, 51, 135-149. [CrossRef]

61. Derhé, M.A.; Murphy, H.; Monteith, G.; Menéndez, R. Measuring the success of reforestation for restoring biodiversity and ecosystem functioning. J. Appl. Ecol. 2016, 53, 1714-1724. [CrossRef]

62. Shoo, L.P.; Storlie, C.; Vanderwal, J.; Little, J.; Williams, S.E. Targeted protection and restoration to conserve tropical biodiversity in a warming world. Glob. Chang. Biol. 2011, 17, 186-193. [CrossRef]

63. Bermingham, E.; Dick, C.W.; CMoritz, C. Tropical Rainforests: Past, Present, and Future; University of Chicago Press: Chicago, IL, USA, 2005.

64. Metcalfe, D.J.; Ford, A.J. Floristics and plant biodiversity of the rainforests of the Wet Tropics. In Living in a Dynamic Tropical Forest Landscape; Stork, N.E., Turton, S.M., Eds.; Blackwell Publishing: Hoboken, NJ, USA, 2008.

65. Braverman, I. Captive for Life: Conserving extinct in the wild species through ex situ Breeding. In The Ethics of Captivity; Lori, G., Ed.; Oxford University Press: Oxford, UK, 2014; pp. 193-212.

66. Taylor, G.; Canessa, S.; Clarke, R.H.; Ingwersen, D.; Armstrong, D.P.; Seddon, P.J.; Ewen, J.G. Is reintroduction biology an effective applied science? Trends Ecol. Evol. 2017, 32, 873-880. [CrossRef] [PubMed]

67. Canessa, S.; Converse, S.J.; West, M.; Clemann, N.; Gillespie, G.; McFadden, M.; Silla, A.J.; Parris, K.M.; McCarthy, M.A. Planning for ex-situ conservation in the face of uncertainty. Conserv. Biol. 2015, 30, 599-609. [CrossRef] [PubMed]

68. Schwartz, K.R.; Parsons, E.C.M.; Rockwood, L.; Wood, T.C. Integrating In-Situ and Ex-Situ Data Management Processes for Biodiversity Conservation. Front. Ecol. Evol. 2017, 5, 120. [CrossRef]

69. Australian Tropical Herbarium (Unpublished Data) Extracted from Queensland Nature Conservation (Plants) Regulation. 2020. Available online: www.legislation.qld.gov.au/view/html/inforce/current/sl-2020-0137 (accessed on 1 January 2021).

70. Field, J.H.; Kealhofer, L.; Cosgrove, R.; Coster, A.C. Human-environment dynamics during the Holocene in the Australian Wet Tropics of NE Queensland: A starch and phytolith study. J. Anthr. Archaeol. 2016, 44, 216-234. [CrossRef] 
71. Ainsworth, T.D.; Heron, S.F.; Ortiz, J.C.; Mumby, P.; Grech, A.; Ogawa, D.; Eakin, C.M.; Leggat, W. Climate change disables coral bleaching protection on the Great Barrier Reef. Sci. 2016, 352, 338-342. [CrossRef]

72. Perry, J.; Falzon, C. Climate Change Adaptation for Natural World Heritage Sites: A Practical Guide; UNESCO: Paris, France, 2014; Volume 37.

73. Phillips, H. Adaptation to Climate Change at UK World Heritage Sites: Progress and Challenges. Hist. Env. Policy Pr. 2014, 5, 288-299. [CrossRef]

74. United Nations Educational, Scientific and Cultural Organisation (UNESCO). Convention Concerning the Protection of the World Cultural and Natural Heritage, Adopted by the General Conference at Its Seventeenth Session Paris; UNESCO: Paris, France, 1972; 17p.

75. Elemide, O.A. Climate change mitigation through environmental intensification a case study of Sub-Sahara African. In ASABE 1st Climate Change Symposium: Adaptation and Mitigation Conference Proceedings; American Society of Agricultural and Biological Engineers: St. Joseph, MI, USA, 2015.

76. Reef Restoration and Adaptation Program for the Great Barrier Reef. 2021. Available online: https://gbrrestoration.org/ (accessed on 1 January 2021). 